\title{
DAMPAK-DAMPAK COVID-19 YANG DIRASAKAN \\ BAGI KEHIDUPAN MAHASISWA
}

\author{
Arimatea \\ Program Studi Psikologi, Fakultas Kedokteran, Universitas Lambung Mangkurat, \\ Email:2010914210019@mhs.ulm.ac.id
}

\begin{abstract}
ABSTRAK
Seperti layaknya tamu yang tak diundang, itu lah fakta tentang virus mematikan yang telah menyebar dalam dunia ini dengan sangat cepat yaitu SARS-COV-2 yang menyebabkan penyakit Covid-19. Covid-19 membuat satu dunia menjadi kacau. Akibatnya banyak segala rencana yang telah dipersiapkan jauh-jauh hari menjadi tak terlaksanakan dan dibatalkan. Segala pekerjaan juga terhambat. Banyak orang-orang di PHK karena perusahaan atau pelaku usaha tidak mampu membiayai pegawainya karena krisis ekonomi. Tentunya kegiatan perekenomian pun menjadi kacau balau. Ditambah banyaknya orang-orang yang terkena virus ini. Banyak juga para tenaga medis yang telah gugur dalam berperang melawan virus dan penyakit ini. Masyarakat pasti sangat merasa dampak yang terjadi akibat jahatnya virus dan penyakit ini. Dan juga dalam bidang pendidikan medapat imbasnya, salah satu adalah mahasiswa yang merasakan dampak dari pandemi ini.
\end{abstract}

\begin{abstract}
Like uninvited guests, that is the fact about the deadly virus that has spread in this world very quickly, namely SARS-COV-2 which causes the Covid-19 disease. Covid-19 throws a world into chaos. As a result, many of the plans that had been prepared in advance were canceled and canceled. All work is also hampered. Many people were laid off because the company or business actor was unable to finance their employees because of the economic crisis. Of course, the economic activities became chaotic. Plus the number of people affected by this virus. Many medical personnel have also died fighting against this virus and disease. The public must have felt the impact that was caused by the evil of this virus and disease. And also in the field of education it gets the impact, one of them is students who feel the impact of this pandemic.
\end{abstract}

Kata Kunci. Dampak, Pandemi, COVID-19, Mahasiswa. 


\section{PENDAHULUAN}

Tahun 2020 adalah tahun yang mungkin dapat dibilang menjadi tahun yang sangat berat bagi semua orang. Karena munculnya virus Covid19 ini membuat tahun ini menjadi sangat kacau. Banyak masalah sekali kejadian-kejadian yang terjadi pada tahun ini. Dimana mebuat semua orang stress dan juga kebingungan saat ingin melakukan kegiatan. Karena saat kita ingin keluar saja banyak pertimbangan yang kita pikirkan. Contohnya seperti apakah tempat yang kita tuju itu aman dari kerumunan yang dapat membuat penyebaran penyakit ini, lalu kita harus memakai masker, menggunakan handsanitizer, menjaga jarak juga dengan orang lain yang membatasi interaksi. Lalu, ditambah dengan ketakutan yang ada dalam pikiran membuat kita takut untuk berinteraksi dengan orang lain. Lalu, pekerjaan juga menjadi kacau karena tidak dapat melakukan pekerjaan secara langsung. Menjadi susah dalam bekerja karena semua pekerjaan dilaksanakan di rumah saja. Karena tidak ada interaksi membuat pekerjaan terasa susah. Lalu juga berdampak pada perekonomian masyarakat. Kegiatan perekonomian seperti berdagang di pasar, tokotoko yang ada di tempat seperti mall, restoran, hotel, bioskop, tempat wisata dan tempattempat lainnya yang menjadi tempat bekerja untuk menghasilkan uang semuanya harus ditutup. Lalu, bagaimana dengan para pekerja yang bekerja dalam tempat-tempat itu jika tempat bekerjanya harus ditutup sampai saat yang tidak kita ketahui? Mau tidak mau pemimpin tempat usaha harus melakukan pemutusan kontrak kerja kepada para pekerjaan agar tempat usahanya tidak bangkrut. Kegiatan pemerintahan pun mendapatkan dampaknya. Karena pemerintah harus memikirkan secara ekstra bagaimana caranya pemerintah dapat tetap menjalankan pemerintahan dengan baik di masa pandemi yang dimana semuanya harus menaati protokol kesehatan yang telah dibuat. Lalu pada bidang kesehatan yang paling merasakan dampak dari pandemi ini. Semua tenaga medis seperti dokter, perawat, petugas rumah sakit dan lembaga penanggualangan bencana dalam menghadapi pandemi ini telah berjuang secara maksimal dalam menangani para pasien yang terkena Covid-19, mereka rela untuk meninggalkan keluarganya demi merawat para pasien yang terkena Covid-19. Kita harus mengapreasiasi para tenaga medis yang telah berjuang di garda terdepan dalam melawan Covid-19 ini. Pastinya semua masyarakat mendapatkan dampak dari pandemi ini yang membuat segala aktifitas, pekerjaan kita semua terganggu dan tidak dapat berjalan secara normal seperti dulu. Kita hanya bisa berharap bahwa semoga pandemi ini dapat cepat berlalu dan semoga kegiatan kita dapat berjalan seperti sedia kala dan berjalan normal lagi karena pastinya kita semua sudah lelah, sudah jenuh dengan pandemi ini selama kurang lebih 8 bulan terakhir. Dan pada artikel ini penulis akan membahas apa saja dampak yang dirasakan atau dialami oleh mahasiswa selama masa pandemi ini yang membuat segala kegiatan perkuliahan dilakukan secara daring dan tidak dapat dapat bertemu secara langsung dengan teman-teman juga dosen terutama pada mahasiswa baru yang selama perkuliahan semester 1 ini berjalan hanya dilakukan secara 
online atau daring saja dan tidak pernah bertemu satu sama lain dengan teman-teman secara langsung.

\section{METODE}

Dalam artikel ini, metode yang digunakan adalah metode kajian literatur dengan menggunakan referensi dari beberapa jurnal yang berisi tentang dampak-dampak yang dirasakan oleh mahasiswa akibat adanya pandemi Covid-19.

\section{PEMBAHASAN}

Dunia Pendidikan, menjadi salah satu bidang yang terdampak dari masa pandemi ini. Mulai yang awalnya sekolah hanya diliburkan selama 2 minggu, dan ternyata pandemi ini semakin tersebar luas sehingga menbuat kegiatan proses belajar mengajar dilaksanakan di rumah saja. Mahasiswa adalah salah satu yang terdampak. Banyak kegiatan mahasiswa yang menjadi terhambat karena semuanya harus dilaksanakan di rumah saja. Namun meski hanya di rumah saja selama masa pandemi, selama perkuliahan juga mahasiswa tetap bisa diselingi dengan melakukan kegiatan positif lainya. Menulis di masa pandemi ini mungkin bisa menjadi salah satu kegiatan yang dapat dilakukan oleh seorang mahasiswa yang terkena dampak dari adanya Covid-19. Menulis kapan saja, dimana saja, dan ketika sedang melakukan apa saja (Abbas \& Erlyani, 2020) itu mungkin menjadi alasan menulis dapat dilakukan oleh mahasiswa di saat pandemi seperti ini. "Tulislah apa yang ada dipikiran bukan memikirkan apa yang akan ditulis" (Abbas, 2020), kutipan tersebut juga dapat membantu mahasiswa ketika menulis. Dan sekarang penulis akan membahas apa saja dampak yang dirasakan oleh mahasiswa terutama pada mahasiswa baru yang baru saja memasuki dunia perkuliahan. Mungkin yang dapat kita lakukan sebagai mahasiswa selama masa pandemi ini ya melakukan perkuliahan secara online, mengikuti organisasi juga secara online yang memberikan dampak yang berbeda-berbeda pada setiap mahasiswa tentunya. Berikut ini adalah dampak-dampak yang kita sebagai mahasiswa rasakan akibat adanya pandemi Covid-19.

\section{Semua Kegiatan dilakukan secara online}

Dalam masa pandemi ini, tentunya semua kegiatan kita dilakukan secara daring semua dan tidak dapat dilakukan secara tatap muka agar penyebaran Covid-19 ini tidak semakin meluas lagi. Salah satu yang melakukannya adalah mahasiswa. Sejak diawal pandemi ini berlangsung, yang awalnya hanya diliburkan saja tetapi malah ditetapkan untuk perkuliahan dilakukan secara online atau daring agar terhindar dari Covid-19 yang menurut penulis sangat jahat ini. Semua dari perkuliahan dilakukan secara online, organisasi juga dilakukan secara online walaupun juga ada dilakukan kegiatan organisasi tatap muka tapi mestinya dilakukan dengan mematuhi protokol kesehatan yang ketat. Dan bagaimana dengan mahasiswa baru yang baru saja memasuki dunia perkuliahan tetapi langsung dihadapi dengan pandemi ini? Awalnya ya sama juga diliburkan saat di SMA selama 2 minggu tapi ternyata 
libur terus diperpanjang hingga akhirnya Ujian Nasional pun ditiadakan. Ujian kelulusan pun dilaksanakan secara online dan tentunya kelulusan juga secara online. Dan sampai ujian masuk perguruan tinggi walaupun tetap dilaksanakan secara langsung tetapi harus tetap menjaga protokol kesehatan. Karena situasi yang semua serba online pun membuat mahasiswa baru harus lebih ekstra dalam menyesuaikan diri dan beradaptasi dalam lingkungan perkuliahan yang dilakukan semuanya secara online.

\section{Mental mahasiswa yang menjadi korbannya}

Di masa pandemi ini, tentunya membuat semua orang menjadi stress akibat banyak nya perubahan yang terjadi. Salah satu nya adalah mahasiswa. Mahasiswa yang awalnya berkuliah secara bertatap muka bersama temanteman dan juga dosen harus melakukan perkuliahan secara online. Perkuliahan online ini dianggap tidak efektif karena fokus kita terbagi menjadi beberapa hal yaitu kuliah dan juga pekerjaan rumah sehingga kuliah online menjadi tidak fokus, mahasiswa juga tidak memahami materi yang diberikan dosen secara maksimal karena fokusnya terbagi. Tugas-tugas juga mungkin diberikan lebih banyak karena kita secara online dan juga beban terasa lebih banyak sehingga membuat mahasiswa menjadi stress. Lalu untuk mahasiswa baru juga harus beradaptasi dengan kondisi seperti yang seharusnya mereka mengawali masa perkuliahan ini dengan tatap muka secara langsung tetapi harus dilaksanakan secara online saja. Perkuliahan juga membaut kaget karena sangat berbeda dengan yang dilakukan saat di sekolah di tambah dengan masa pandemi ini mungkin dapat membuat mahasiswa baru menjadi stress juga.

\section{Sulitnya mencari pekerjaan untuk mahasiswa yang baru lulus}

Tidak hanya berdampak pada mahasiswa yang sedang menjalani perkuliahan saja, tapi masa pandemi sekarang juga berdampak pada mahasiswa yang baru saja lulus dari bangku perkuliahan/fresh graduate. Karena banyaknya lapangan pekerjaan sekarang yang ditutup, para pekerja juga di PHK, membuat semakin banyaknya lulusan-lulusan yang tidak bekerja. Mau tidak mau untuk memenuhi kebutuhan hidupnya, seorang mahasiswa yang baru saja lulus di masa pandemi seperti sekarang pasti banyak berpikir untuk membuka usaha sendiri agar dapat bertahan hidup walaupun keuntungan dari usaha yang dijalankan masih belum tahu seperti apa dikarenakan masa pandemi ini.

Selain dampak negatif yang dirasakan oleh mahasiswa-mahasiswa, tentunya juga ada dampak positif yang dapat dirasakan oleh mahasiswa. Berikut ini adalah beberapa dampak positif yang dirasakan oleh mahasiswa.

\section{Meningkatkan penggunaan teknologi}

Akibat adanya pandemi ini membuat semua pembelajaran dilakukan secara online atau di rumah saja. Belajar selama pandemi Covid-19 
mengurangi penggunaan media pembelajaran tradisional dan memaksimalkan penggunaan peralatan yang lebih berteknologi maju. Dalam proses pembelajaran baik dosen maupun mahasiswa dapat menggunakan smartphone atau laptop dengan koneksi internet, dan konon penggunaan teknologi mobile semakin meningkat di perguruan tinggi. Perangkat saat ini memiliki konektivitas yang mendukung akses ke materi yang tersedia di Web, oleh karena itu banyak pelajar, terutama pelajar di negara berkembang, menggunakannya sebagai alat pendukung untuk berpartisipasi dalam pembelajaran online.

\section{Membuat mahasiswa lebih mandiri dalam proses belajar}

Di luar dugaan, penerapan pembelajaran secara online atau daring justru akan berdampak positif bagi kemandirian belajar mahasiswa. Minimnya pembelajaran oleh dosen fisika membatasi komunikasi antara dosen dan mahasiswa. Perkuliahan yang diberikan dosen melalui ruang kelas virtual dirasa kurang, sehingga mahasiswa aktif mencari dan menggunakan bahan referensi lain untuk menunjang pemahamannya terhadap materi perkuliahan; pembelajaran online oleh dosen mendorong mahasiswa untuk lebih aktif belajar. Harapan untuk mengetahui materi ajar yang dibagikan oleh dosen melalui aplikasi pembelajaran atau aplikasi instant messaging, yang memungkinkan mahasiswa aktif membaca, berdiskusi dengan teman sebaya atau langsung bertanya.

\section{KESIMPULAN}

Masa pandemi ini memberikan dampak yang sangat mempengaruhi bagi semua orang. Mulai berdampak dari kegiatan perekonomian, pemerintahan, dan juga tentunya bagi Pendidikan juga. Salah satu yang merasakan dampaknya dalam bidang Pendidikan adalah mahasiswa. Pandemi ini memberikan dampak negatif dan juga dampak positif bagi mahasiswa. Beberapa dampak negatif yang terjadi bagi mahasiswa adalah semua kegiatan perkuliahan dilakukan secara online, lalu mental mahasiswa yang menjadi korbannya, dan sulitnya mencari pekerjaan untuk mahasiswa yang baru lulus. Dan beberapa dampak positif yang dirasakan mahasiswa adalah dapat meningkatkan penggunaan teknologi dan juga dapat membuat mahasiswa lebih mandiri dalam proses belajar. Kita semua berharap semoga pandemi cepat berlalu dan juga kita berharap semoga kita dapat menjalani kegiatan kita seperti sedia kala. Terimakasih. 


\section{DAFTAR PUSTAKA}

Abbas, E. W., \& Erlyani, N. (2020). Menulis di Kala Badai Covid-19.

Abbas, E. W. (2020). Ersis Writing Theory: Cara Mudah Menulis.

Abbas, E. W. (2016). Mengatasi Kesulitan Menulis.

Abbas, E. W. (2015). Menulis Mengasyikkan.

Abbas, E. W. (2020). Menulis Artikel Jurnal. Menulis Artikel Jurnal.

Amini, M., Mayangsari, M. D., \& Zwagery, R. V. (2020). Hubungan antara Kemandirian Belajar dengan Komitmen Tugas pada Mahasiswa Program Studi Psikologi. Jurnal Kognisia: Jurnal Mahasiswa Psikologi Online, 2(2), 149-152.

Argaheni, N. B. (2020). Sistematik Review: Dampak Perkuliahan Daring Saat Pandemi COVID-19 Terhadap Mahasiswa Indonesia. PLACENTUM: Jurnal Ilmiah Kesehatan dan Aplikasinya, 8(2), 99-108.

Engko, C., \& Usmany, P. (2020). Dampak Pandemi Covid-19 Terhadap Proses Pembelajaran Online. Jurnal Akuntansi, 6(1), 23-38.

Husna, T. A., Mayangsari, M. D., \& Rachmah, D. N. (2018). Peranan Kecerdasan Spiritual Terhadap Regulasi Diri Dalam Belajar Pada Santriwati Di SMP Darul Hijrah Puteri Martapura. Jurnal Ecopsy, 5(1), 51-56.

Kusnayat, A., Muiz, M. H., Sumarni, N., Mansyur, A. S., \& Zaqiah, Q. Y. PENGARUH TEKNOLOGI PEMBELAJARAN KULIAH ONLINE DI ERA COVID-19 DAN DAMPAKNYA TERHADAP MENTAL MAHASISWA.

Napitupulu, R. M. (2020). Dampak pandemi Covid-19 terhadap kepuasan pembelajaran jarak jauh. Jurnal Inovasi Teknologi Pendidikan, 7(1), 23-33.

Pujilestari, Y. (2020). Dampak Positif Pembelajaran Online Dalam Sistem Pendidikan Indonesia Pasca Pandemi Covid-19. 'ADALAH, 4(1).

Rachmah, D. N., Mayangsari, M. D., \& Akbar, S. N. (2015). Motivasi belajar sebagai mediator hubungan kecerdasan adversitas dan prokrastinasi akademik pada mahasiswa yang aktif berorganisasi. Jurnal Cakrawala Pendidikan, 34(2).

Shadiqi, M. A. Memahami dan Mencegah Perilaku Plagiarisme dalam Menulis Karya Ilmiah. Buletin Psikologi, 27(1), 30-42. 
Siahaan, M. (2020). Dampak Pandemi Covid-19 Terhadap Dunia Pendidikan. Dampak Pandemi Covid-19 Terhadap Dunia Pendidikan, 20(2).

Ulfa, Z. D., \& Mikdar, U. Z. (2020). Dampak Pandemi Covid-19 terhadap Perilaku Belajar, Sosial dan Kesehatan bagi Mahasiswa FKIP Universitas Palangka Raya. JOSSAE (Journal of Sport Science and Education), 5(2), 124-138.

WARMANSYAH ABBAS, E. R. S. I. S. (2020). Menulis di Era Covid-19: Memanage Trauma Psikologis Menghindari Psikosomatis. Menulis di Era Covid-19: Memanage Trauma Psikologis Menghindari Psikosomatis. 